\title{
DEMARCAÇÃO CIENTÍFICA E A SOCIOLOGIA DO DIREITO
}

Artur Stamford da Silva

(Editor)

O que caracteriza uma pesquisa como sociológica do direito? Como sei que minha pesquisa é sociológica e não dogmática? Somos remetidos a essas questões por graduandos, pós-graduandos, docentes e profissionais, bem como a cada pedido de indexação, quando temos que preencher formulários detalhando o escopo da revista. Em tempos de MITdisciplinariedade, como escrevemos no volume anterior, isso soa estranho. Ou seguimos disciplinares, mas disfarçados?

Se em tempos de Eugen Ehrlich (1862-1922), Max Weber (1864-1920), Santi Romano (1875-1947), Hermann Kantorowicz (1877-1940), Kans Kelsen (1881-1973), Alf Ross (1889-1975), Carlos Cossio (1903-1987) foi fundamental definir O objeto e O método da ciência do direito, como se fosse fundamental estabelecer o espaço da dogmática e o da sociologia do direito, não reconhecemos qualquer utilidade ou necessidade para decretar essa uma definição.

Acusamos Karl Popper (1902-1994) e Paul Feyerabend (1904-1994) como responsáveis por nos dispensar dessa amarra de ter uma definição de sociologia do direito, afinal ciência não tem por função estabelecer conceitos. A busca de Popper para demarcar a ciência e a concepção da indispensável liberdade do pesquisador para fazer pesquisa científica, de Feyerabend, nos levaram a reconhecer que não é determinando objeto e método que se estabelece uma área do saber, em nosso caso, da sociologia do direito. Antes, reconhecer que não é a temática nem o método o que faz uma reflexão ter cunho sociológico é reconhecer que o pensar sociologicamente o direito, para repisar uma expressão de Cláudio Souto, está na criticidade que busca conhecer o normativo como justiça, esteja ele no Estado, num grupo social ou noutros espaços sociais.

Não ter uma definição não se confunde com não saber distinguir, comunicar.

Com este volume destacamos a amplitude temática da sociologia do direito, como se pode observar com os artigos deste volume 4, número 1, jan./abr. 2017 da Revista Brasileira de Sociologia do Direito (RBSD). Se a amplitude temática, epistemologicamente, é apontada como falta de delimitação do objeto de uma área do conhecimento e, por 
consequência, acusa não haver cientificidade. A ABraSD e a RBSD se afastam desse purismo epistêmico para se unir às ousadias dos pesquisadores que preferiam desenvolver pesquisas não puristas mas revolucionárias.

Para quem ciência não se confunde com disputa por espaço e poder, a exemplo das abordagens multi-inter-trans disciplinares, como comentamos na RBSD passada, amplitude temática é um ganho, pois a diversidade metodológica é atratora e não excludente. Unir pesquisadores em pesquisa é missão da ABraSD e a RBSD se aponta como veículo para esta missão.

Por tudo isso, tem lugar neste volume o aporte linguístico do dialogismo de Bakhtin para criticar a prática forense do contraditório, como escreve David Oliveira; a sociologia e a ciência política da maldade, da condição humana como aporte para criticar as práticas de comandos em situações de violência, como no nazismo, como escreve Fabiano Miranda do Nascimento Tizzo; o recurso à filosofia ética, à representação da realidade para tecer críticas às quatro etapas da história do conhecimento, iniciando com a "coisa em si", passando pelo idealismo, pelo giro linguístico até a escatologia de quem pretende "construir uma ética primeira", com Davi Augusto Santana de Lelis; o realismo e pragmatismo com sua teoria preditiva como via para criticar a decisão jurídica, nas palavras de Matheus de Mendonça Gonçalves Leite; o universalismo e o relativismo cultural como central para debater o lugar dos direitos humanos, se como instrumento de poder ou de emancipação, como escrevem, Moisés Saraiva de Luna e Lidia Almeida de Oliveira. Temos ainda três pesquisas que tratam da vida cotidiana "nua e crua": a primeira trata de vivências no setor de celulose em Três Lagoas, estado do Mato Grosso do Sul, com Cláudio Ribeiro Lopes e Napoleão Miranda; a segunda, sobre "Revolução Verde", trazendo a concepção de terra sob a ótica de agricultores familiares, nações indígenas, comunidades quilombolas e outros povos tradicionais, com Luís Felipe Perdigão de Castro; e a terceira, pesquisa a questão urbana em Fortaleza, com Harley Sousa de Carvalho e Rafael Mesquita Ferreira Freitas.

Como se pode ler dos textos, mesmo sem uma definição de sociologia do direito nem de pesquisa científica, não deixamos de reconhecer quando um trabalho não é sociológico do direito, não é pesquisa científica. Sabemos sim diferenciar, identificar e reconhecer o que é pensar sociologicamente o direito.

Sigamos em pesquisa sociológica do direito, portanto, fazendo ciência! 